\title{
Stephanthus antarcticus, a new genus and species of sea anemone (Actiniaria, Haloclavidae) from the South Shetland Islands, Antarctica
}

Received: 12 April 2002 / Revised: 12 November 2002 / Accepted: 12 November 2002 / Published online: 24 January 2003

C) Springer-Verlag and AWI 2003

\begin{abstract}
Stephanthus antarcticus gen. nov. et sp. nov. is described and illustrated from six specimens collected in the Antarctic Peninsula on the Polarstern cruises ANT XV/3 and ANT XIX/3. The new genus is characterised by the absence of sphincter and basilar musculature, the presence of a single strong siphonoglyph with a basal enlargement, distinct parietobasilar musculature, tentacles without acrospheres, two cycles of six pairs of mesenteries (only one of them perfect), and a deep fosse with parapet; another remarkable feature is the absence of microbasic p-mastigophores. The new genus shows characteristics of three families of soft-bottomdwelling sea anemones, namely Haloclavidae Verrill, 1899, Halcampoididae Appellöf, 1896, and Andresiidae Stephenson, 1922. The generic characters of Stephanthus gen. nov. are discussed and it is tentatively placed in the family Haloclavidae.
\end{abstract}

Keywords Stephanthus · Haloclavidae - Actiniaria . South Shetland Islands · Antarctica

\section{Introduction}

The unexplored portions of the world's oceans are so vast that the descriptive stage of their faunas is far from being completed. Although during recent years research into Antarctic biodiversity has been intensified, the Anthozoan fauna is not well known, our present knowledge being estimated to encompass no more than 50\% (Winston 1992).

Communicated by H.-D. Franke

E. Rodríguez $(\bowtie) \cdot$ P. J. López-González

Departamento de Fisiología y Zoología, Facultad de Biología, Universidad de Sevilla, Reina Mercedes 6, 41012 Sevilla, Spain e-mail: fani@us.es

Fax: +34-954-233480

E. Rodríguez

Departament de Biología Marina i Oceanografia,

Institut de Ciències del Mar, CMIMA (CSIC),

Passeig Marítim de la Barceloneta 37-49, 08003 Barcelona, Spain
The Antarctic Peninsula is one of the most interesting and most thoroughly studied areas of Antarctica and significant contributions on Anthozoan taxonomy have been published in the last few decades (see, for additional references, Bayer 1981; Dunn 1983; Fautin 1984; Arntz et al. 1994; Williams 1999; López-González and Gili 2001; Rodríguez and López-González 2002). The Antarctic Peninsula is connected, from a biogeographical point of view, to the Magellan region through the Scotia Arc, one of the corridors supposedly responsible for the migration processes of marine benthic fauna (Watling and Thurston 1989; Arntz and Gallardo 1994). Thus, efforts to increase our knowledge of the benthic fauna in this area are necessary not only to complete our knowledge of the Anthozoan fauna but also to go further in our understanding of the processes involved in the origins of the extant Antarctic fauna.

Six individuals of an undescribed sea anemone genus and species were collected on the Antarctic Polarstern cruises ANT XV/3 and ANT XIX/3. The new genus shares several features with some genera of the families Haloclavidae (Verrill 1899), Halcampoididae (Appellöf 1896) and Andresiidae (Stephenson 1922). The absence of basilar musculature in our material would place it under the tribus Athenaria, but the group is probably polyphyletic (Hand 1966; Schmidt 1972, 1974; RiemannZürneck 1979, 1991, 2000; Shick 1991; Rodríguez and López-González 2002). We therefore prefer not to use this category in the present work. We tentatively place the genus within the family Haloclavidae. Finally, the relationships of this new genus with the most similar haloclavid genera are discussed.

\section{Methods}

The material studied was collected on the Polarstern cruises ANT XV/3 (EASIZ-II) and ANT XIX/3 (ANDEEP-I), sponsored by the Alfred-Wegener-Institut für Polar- und Meeresforschung, Bremerhaven, during the austral summers of 1998 to the eastern Weddell Sea and Antarctic Peninsula (EASIZ-II) and 2002 to the Scotia Arc (ANDEEP-I). 
Sea anemones were relaxed on board using menthol crystals and subsequently fixed in $10 \%$ formalin in seawater. Fragments of the holotype and the larger paratype were dehydrated in buthanol (Johansen 1940), and embedded in paraffin. Histological sections 7-8 $\mu \mathrm{m}$ thick were stained with Ramón and Cajal's Triple Stain (Gabe 1968).

Cnidae measurements were taken from preserved material in squash preparations at $1,000 \times$ magnification with Nomarski differential interference contrast optics. Frequencies given are subjective impressions based on squash preparations.

The material studied in this article has been deposited in the Zoologisches Institut und Zoologisches Museum in Hamburg $(\mathrm{ZMH})$, in the University Natural History Museum in Kansas (KUNHM) and in the Zoology Section of the Faculty of Biology at the University of Seville in Spain (SZ).

\section{Results}

Order Actiniaria Hertwig, 1882

Suborder Nynantheae Carlgren, 1899

Family Haloclavidae Verrill, 1899

\section{Diagnosis}

Body elongate without basilar musculature, aboral end physa-like or forming a physa sometimes broadly adherent. Column either smooth or with hollow or solid papillae or suckers, rarely with cinclides, rarely divisible into physa, scapus and scapulus; in some a parapet and a deep fosse. No sphincter or rarely a weak or moderately developed diffuse one. Tentacles short, sometimes capitate, usually simple, never numerous, the inner shorter or of same length as the outer ones. A single, ventral, usually very strong siphonoglyph, which is occasionally more or less completely separated from the other part of the actinopharynx, and sometimes drawn out at its oral end into a more or less folded conchula. Perfect pairs of mesenteries varying in number, usually all macronemes. Retractors usually strong. Parietobasilar musculature usually distinct.

\section{Remarks}

The diagnosis has been modified from Carlgren (1949, p 29) firstly to accommodate the new genus within the family, by including the possible presence of a deep fosse and a parapet, and following the removal of the genus Oractis McMurrich, 1893 to a new family, Oractiidae, by Riemann-Zürneck (2000), the characters and their variants referring to this genus have been suppressed.

Genus Stephanthus gen. nov.

\section{Diagnosis}

Body more or less ovoid without regional differentiation. Aboral end rounded, physa-like. Scapus with distal dis- tinct parapet and fosse. No sphincter. Tentacles moderate in length, not numerous. Inner tentacles about same length as outer. A single, very strong, siphonoglyph with a basal enlargement. Mesenteries not divisible into macro- and micronemes. Equal number of mesenteries distally and proximally. Six pairs of perfect mesenteries, two pairs of directives. All mesenteries fertile including directives. Retractor musculature diffuse. Parietobasilar musculature distinct. Cnidom: spirocysts, basitrichs and microbasic b-mastigophores; microbasic p-mastigophores absent.

Type species: Stephanthus antarcticus sp. nov.

\section{Etymology}

The genus is named after Professor T.A. Stephenson in recognition of his major contributions to our knowledge in sea anemone systematics, and anthus (anthos-anthus: flower in figurative sense in Greek) being a common suffix in sea anemone generic names. Gender masculine.

\section{Stephanthus antarcticus sp. nov.}

\section{Type material}

Holotype: ZMH (C11680), one specimen, Polarstern ANT XV/3, stn. 48/336, Antarctic Peninsula, 61 ${ }^{\circ} 26.8^{\prime} \mathrm{S}$ $58^{\circ} 06.2^{\prime} \mathrm{W}, 1,047-1,227 \mathrm{~m}$ depth, 19 March 1998, Agassiz trawl. Paratypes: KUNHM (001610), one specimen; ZMH (C11681), one specimen, both materials with the same sampling data as the holotype.

Additional material: SZ (ANT-1282), one specimen, Polarstern ANT XIX/3, stn. PS61/103-1, Antarctic Peninsula, 61 ${ }^{\circ} 44.9^{\prime} \mathrm{S} 58^{\circ} 01.4^{\prime} \mathrm{W}, 256-296 \mathrm{~m}$ depth, 13 February 2002, bottom trawl; SZ (ANT-1281), one specimen, Polarstern ANT XIX/3, stn. PS61/106-1, Antarctic Peninsula, $61^{\circ} 38.2^{\prime} \mathrm{S} 57^{\circ} 32.7^{\prime} \mathrm{W}, 424-427 \mathrm{~m}$ depth, 14 February 2002, bottom trawl; SZ (ANT-1609), one specimen, Polarstern ANT XIX/3, stn. PS61/107-1, Antarctic Peninsula, $61^{\circ} 51.2^{\prime} \mathrm{S} 57^{\circ} 17.6^{\prime} \mathrm{W}, 256-277 \mathrm{~m}$ depth, 14 February 2002, bottom trawl.

\section{Diagnosis}

As for the genus.

\section{Description}

External anatomy (Figs. 1 and 2): Body ovoid to more or less spherical, to $40 \mathrm{~mm}$ diameter and $56 \mathrm{~mm}$ height in preserved and contracted specimens. Aboral end rounded, physa-like. Body without regional differentiation but with a parapet and a deep fosse (Fig. 2A). About 20 longitudinal folds on inner distal border of parapet. Scapus 

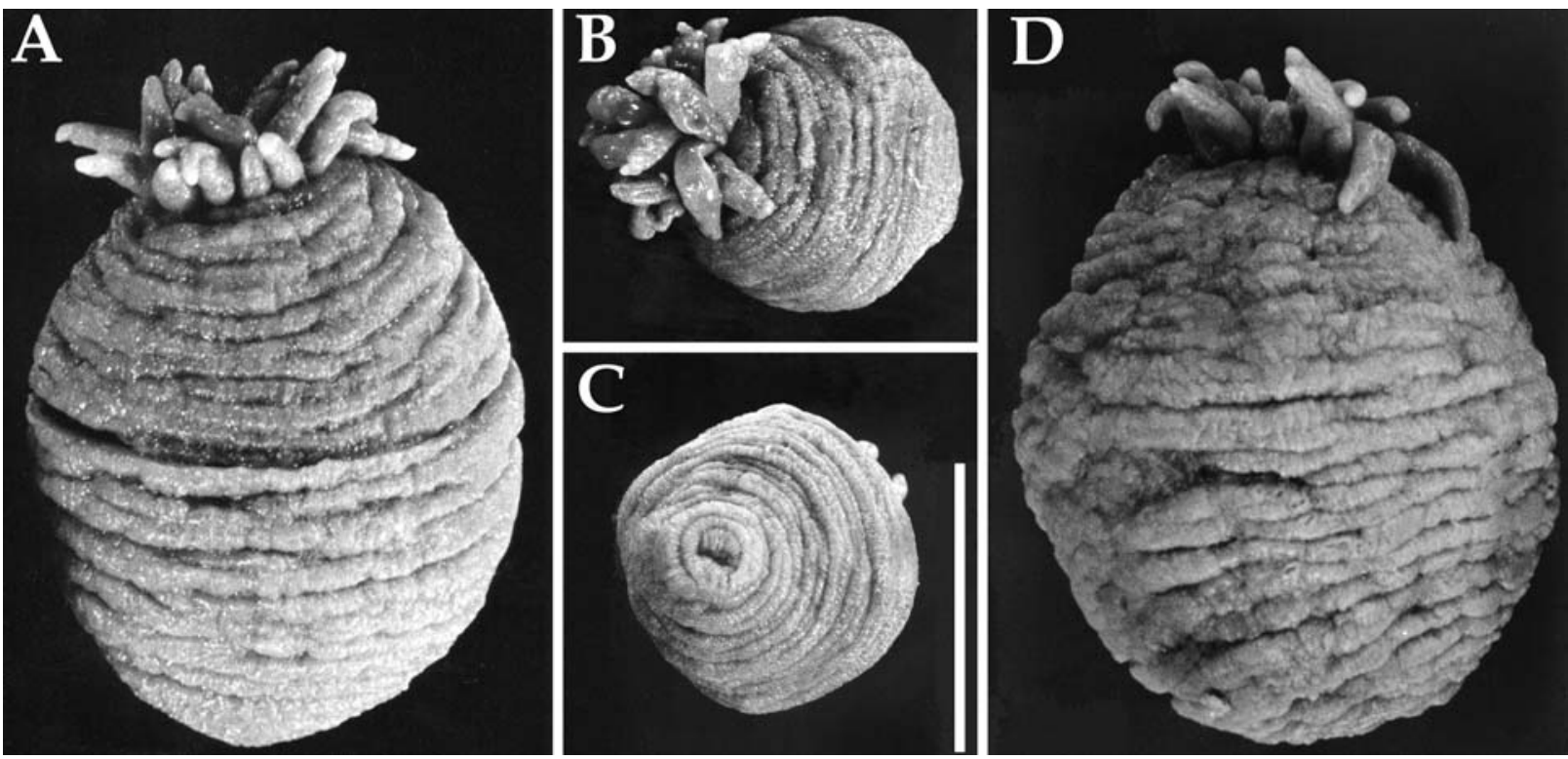

Fig. 1A-D Stephanthus antarcticus gen. nov., sp. nov. A Holotype (ZMH C11680) in lateral view. B, C Paratype (ZMH C11681), lateral and aboral view, respectively; note the rounded aboral end. D Paratype (KUNHM 001610), lateral view. Scale bar 20 mm

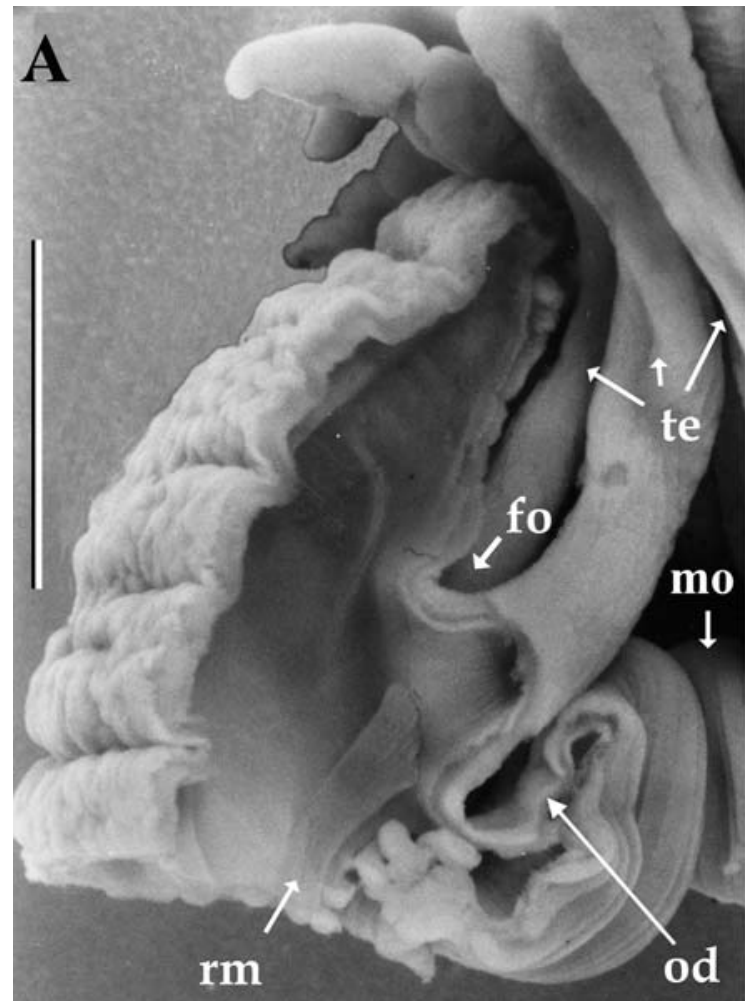

Fig. 2A-D Stephanthus antarcticus gen. nov., sp. nov. (Holotype ZMH C11680). A Preserved specimen, longitudinal section of the distal part of the column and oral disc. B, C Detail of the proximal part of the body wall showing the superficial spots. D Cross section at stomodaeum level of whole animal; note the basal enlargement of the single siphonoglyph. Abbreviations: fo fosse, mo mouth, od oral disc, $r m$ retractor musculature, te tentacles. Scale bars $5 \mathrm{~mm}$
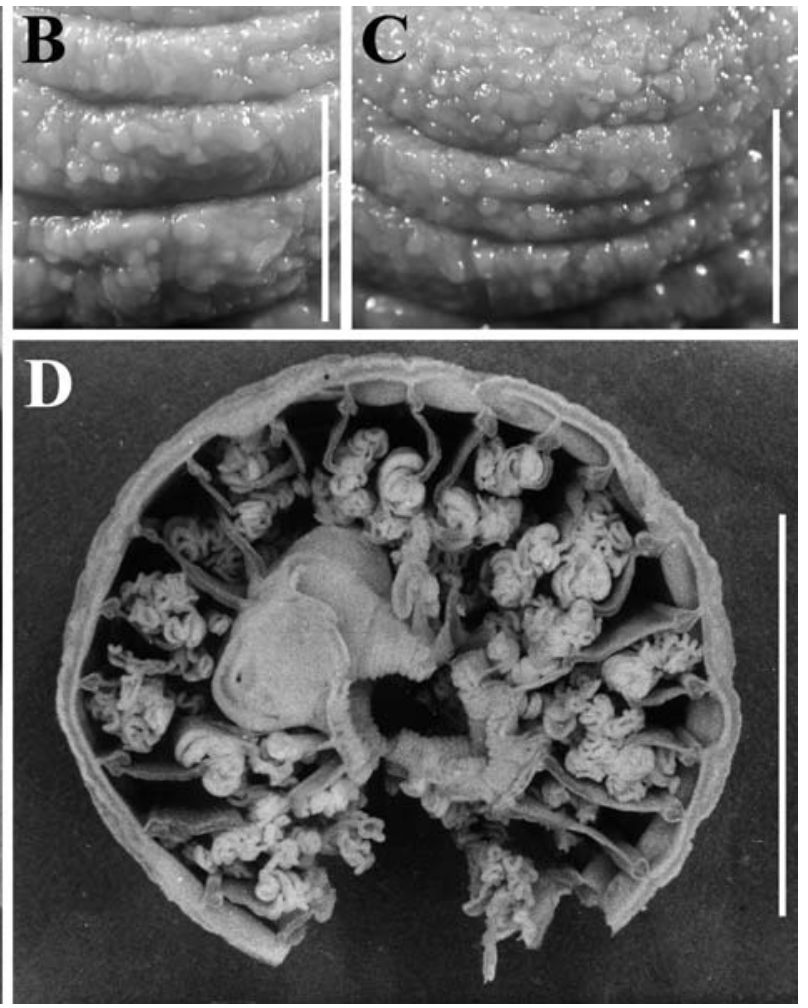

soft and fibrous, corrugated in preserved and contracted specimen, forming deep irregular transversal furrows with numerous small longitudinal furrows. Larger specimens with pale spots slightly restricted to proximal part of scapus; no foreign particles adhered to them (Fig. 2B, C).

Oral disc slightly broader in diameter than proximal end in retracted specimens. Tentacles can be only partially retracted, being only middle covered by the parapet in 


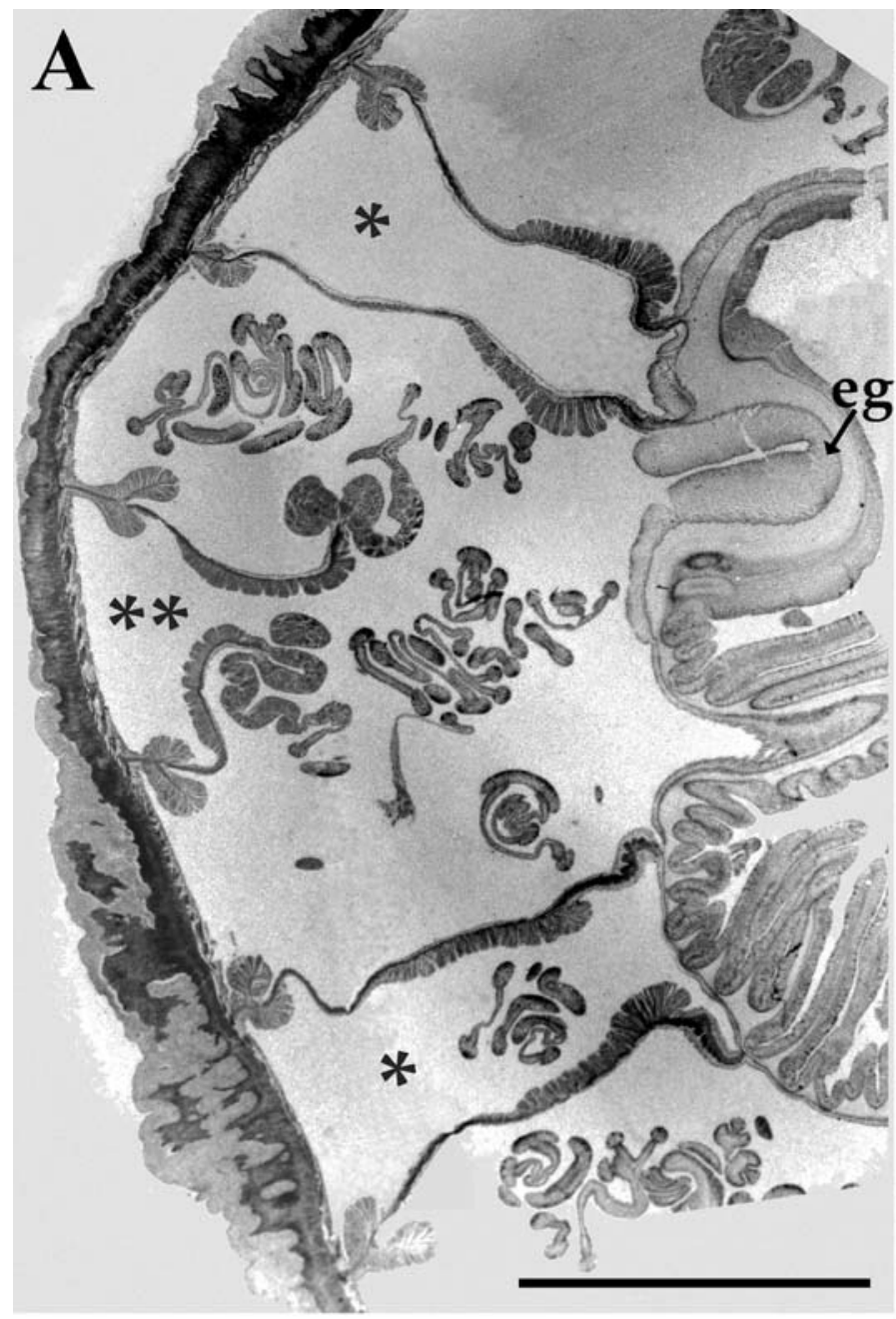

Fig. 3A-C Stephanthus antarcticus gen. nov., sp. nov. A Histological cross section at stomodaeum level (Holotype ZMH C11680). B Detail retractor musculature at most distal level (Holotype ZMH C11680). C Longitudinal histological section of the distal part of the column and oral disc (Paratype KUNHM 001610). Abbreviations: * endocoel between mesenteries of the first cycle, ** endocoel between mesenteries of the second cycle, e.g. basal enlargement of the siphonoglyph, fo fosse, $m s$ mesenteries, $r m$ retractor musculature, te tentacles. Scale bars: A $5 \mathrm{~mm}$, B $3 \mathrm{~mm}$, C $5 \mathrm{~mm}$

all preserved specimens. Tentacles longitudinally furrowed, longer than diameter of the oral disc in preserved specimens. Inner tentacles more or less equal in length (to $27 \mathrm{~mm}$ in preserved specimens) to outer ones, to 24 in number, arranged in three cycles $(6+6+12)$. Oral end of siphonoglyph distinguishable at border of the mouth, but does not form a conchula.

Internal anatomy (Figs. 2D, 3, 4 and 5): Equal number of mesenteries distally and proximally. Mesenteries hexamerously arranged in two cycles: first cycle perfect and fertile; second cycle imperfect and fertile (Fig. 2D). Two pairs of fertile directives, only one connected with the single, strong and well-developed siphonoglyph, with a basal enlargement (Figs. 2D and 3A). Mesogloea and

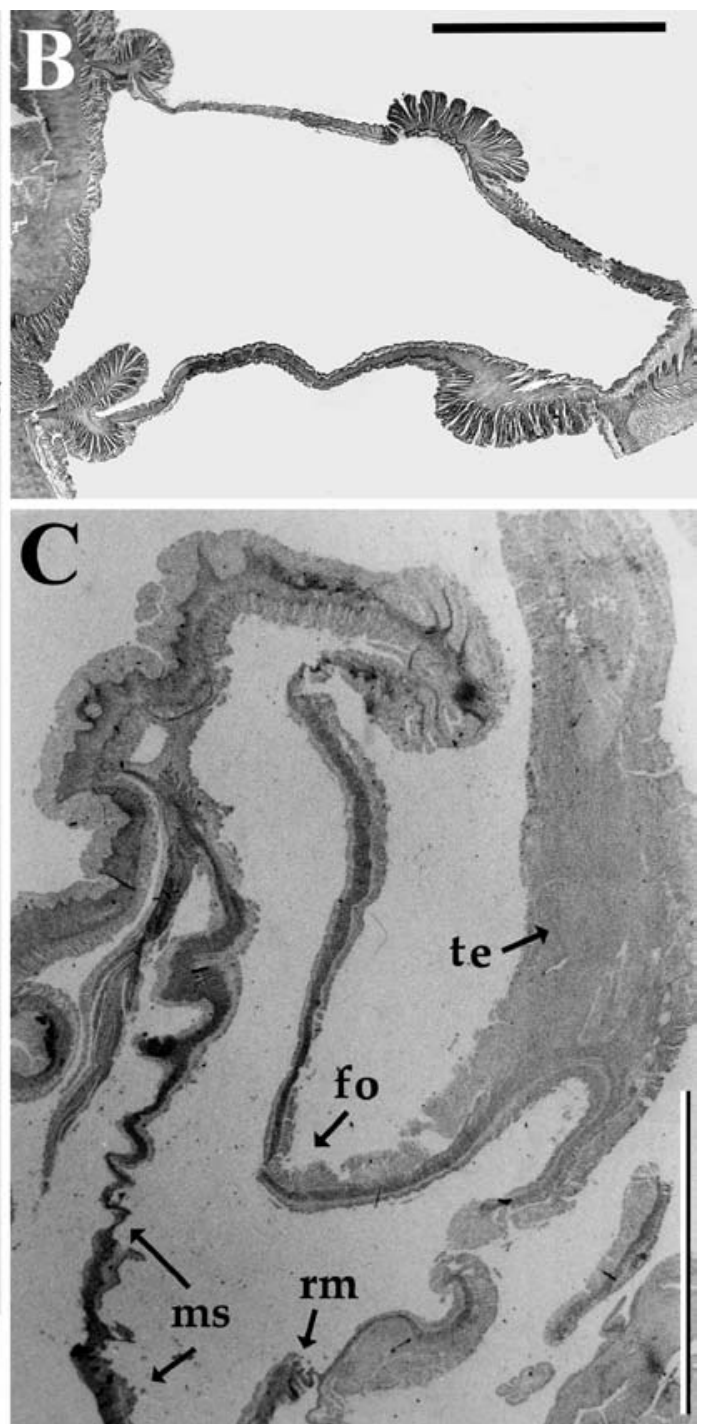

gastrodermis of siphonoglyph slightly wider than mesogloea and gastrodermis of the stomodaeum. Gastrodermis of siphonoglyph not vacuolated. Retractor musculature diffuse at stomodaeum level (Fig. 3A) and attached near to the base of tentacles where it becomes slightly restricted (Fig. 3B). Parietobasilar musculature strong, well developed. Gametogenic tissues well developed in specimens collected in February and March; gonochoric; developing spermatic vesicles and oocytes (to $0.25 \mathrm{~mm}$ and to $1.8 \mathrm{~mm}$ in diameter in preserved specimens, respectively).

Sphincter muscle absent. Tentacles and oral disc with ectodermal longitudinal musculature. No histologically differentiated regions along tentacles. Endodermal circular musculature well developed at mid-column. Column wall of similar thickness entire length, corrugated nature probably due to contraction of the specimens (Fig. 4A). Superficial spots in proximal part of column poorly differentiated in histological sections (Fig. 4B, C). Epidermis $0.1-0.4 \mathrm{~mm}$ thick and fibrous; mesogloea 


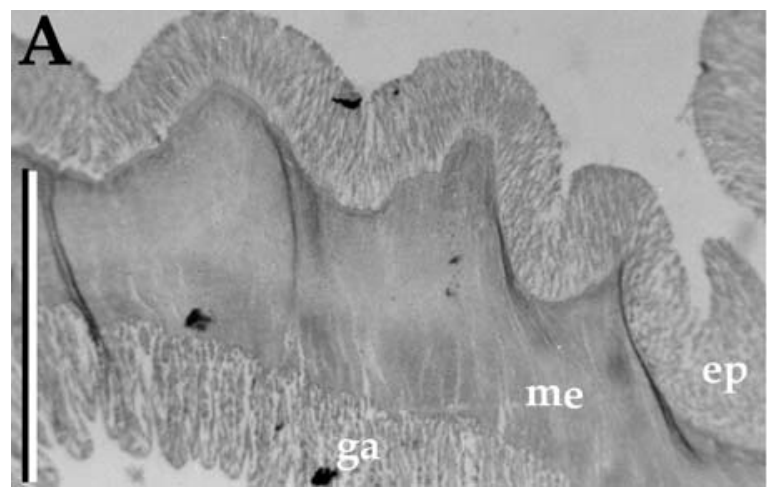

Fig. 4A-C Stephanthus antarcticus gen. nov., sp. nov. Longitudinal sections through the body wall of the holotype (ZMH C11680). A Detail of the body wall. B, C Detail of the proximal part of the body wall showing the superficial spots, which are
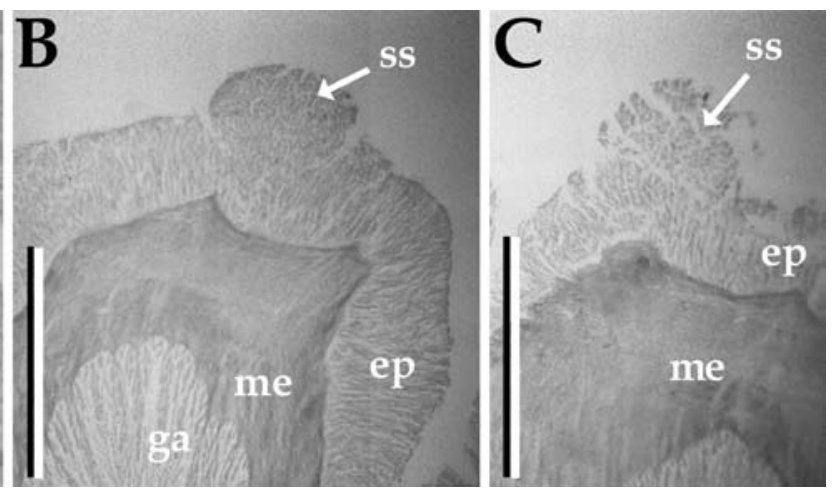

poorly histologically differentiated. Abbreviations: $e p$ epidermis, ga gastrodermis, me mesogloea, ss superficial spots. Scale bars $0.5 \mathrm{~mm}$

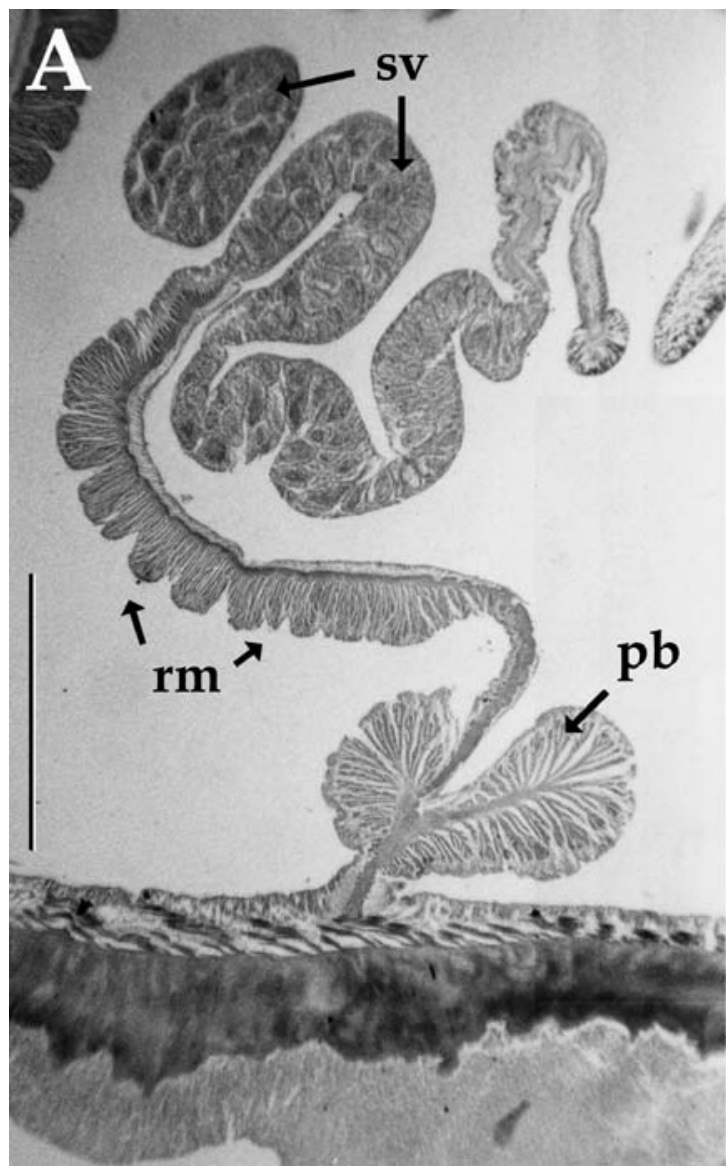

Fig. 5A-C Stephanthus antarcticus gen. nov., sp. nov. (Holotype ZHM C11680). A Detail of cross section showing a second cycle mesentery; note the distinct parietobasilar musculature, the diffuse retractor musculature and the developing spermatic vesicles. B Cross section through a tentacle showing the ectodermal longitudinal musculature; note the subepidermical nerve plexus. C Longitudinal section through the proximal part of the mesenteries showing the absence of basilar musculature. Abbreviations: $e p$ epidermis, $g a$ gastrodermis, $m e$, mesogloea, $n p$, nerve plexus, $p b$, parietobasilar musculature, $r m$, retractor musculature, $s v$, spermatic vesicles. Scale bars: A $1 \mathrm{~mm}$; B, C $0.5 \mathrm{~mm}$
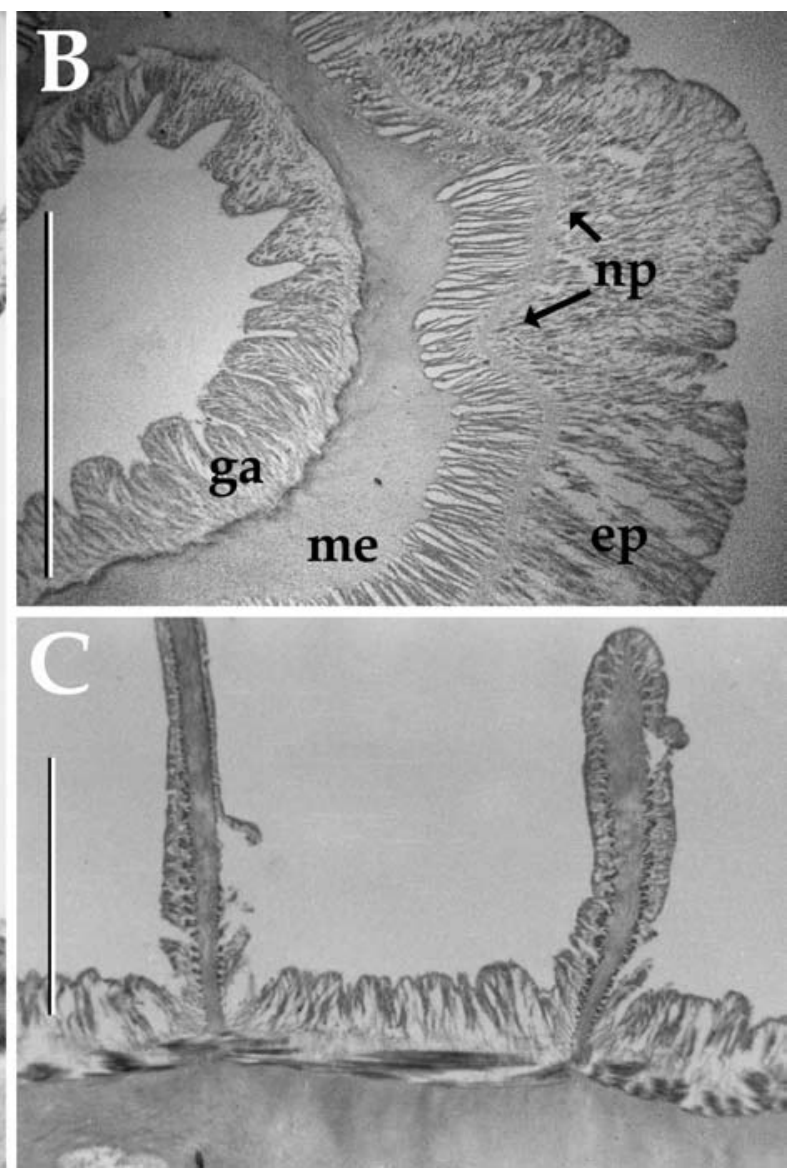

$0.25-1.5 \mathrm{~mm}$ thick, and gastrodermis $0.09-0.33 \mathrm{~mm}$ thick.

Cnidom (Fig. 6): Spirocysts, basitrichs and microbasic b-mastigophores. A survey of the cnidae is presented in Table 1 and Fig. 6.

\section{Colour}

Preserved material of a flesh to brownish colour. 


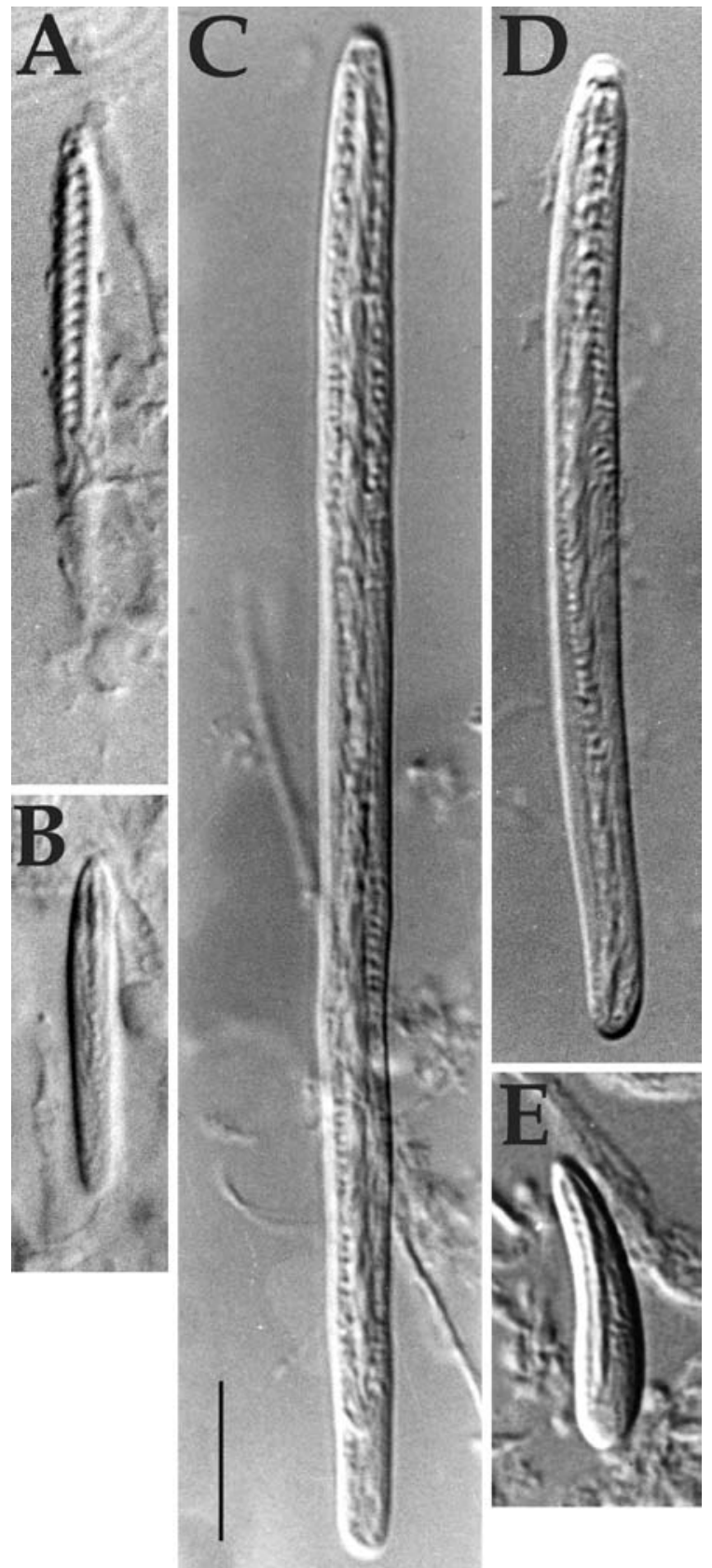

Fig. 6A-E Cnidae of Stephanthus antarcticus gen. nov., sp. nov. A Spirocyst. B Basitrich 1. C Basitrich 2. D Basitrich 3. E Microbasic b-mastigophore. See Table 1 and text for explanation. Scale bar $10 \mu \mathrm{m}$

\section{Etymology}

The specific name antarcticus is chosen because of where the specimens were collected.

\section{Geographic and depth distribution}

Stephanthus antarcticus sp. nov. is known only from the South Shetland Islands, off the Antarctic Peninsula, inhabiting muddy bottom, depth 256-1,227 m.

\section{Discussion}

Familial placement of the new genus

As Manuel (1988) and Rodríguez and López-González (2002) have remarked, the distinctness of the families Haloclavidae and Halcampoididae is not clearly established. Most (if not all) characters given by Carlgren (1949, pp 26, 29), for both families, have a high range of variability, often overlapping between one another, due to the existence of numerous exceptions to the rule, with the text containing terms such as "rarely", "usually", "sometimes", "except in ...".

In the artificial key to "athenarian" families and the subsequent diagnosis given by Carlgren (1949, pp 21, 26, 29), distinguishing characters between the families Haloclavidae and Halcampoididae are reduced to the differential length between inner and outer tentacles and the possible absence of the siphonoglyph in the Halcampoididae.

With regard to the use of the differential length between inner and outer tentacles as a distinctive character at familial level, we think that this should be restricted as a generic feature in these two families. According to Stephenson (1920, p 514), "The form of the tentacles in a preserved specimen will depend chiefly on the circumstances of the animal's death". It is true that in some species their entameric or ectameric nature can be easily established. However, in Stephanthus gen. nov. some of the inner tentacles are longer than the outer ones, some are shorter and others are of about equal length. Thus, the relative length between the inner and the outer tentacles is not so helpful in this case.

The new genus described here is tentatively placed in the family Haloclavidae due to the presence of a single and very strong siphonoglyph with a distinct basal enlargement, the other generic features of Stephanthus gen. nov. being present in both Haloclavidae and Halcampoididae. However, further detailed anatomical (and probably molecular) investigations and reviews of all genera of both families will be necessary to solve the problem of the familial placement of this new genus, and to delimit the boundaries (if they exist) between these two families.

Furthermore, the new genus shows a distinctive character, a deep fosse and parapet. The supposed presence of a fosse and a parapet has been attributed to the genera Peachia (Carlgren 1921, p 98) and Mesacmaea (Carlgren 1949, p 23), but not developed to such an extent as in Stephanthus gen. nov. Thus, the diagnosis given by Carlgren (1949, p 29) of the family Haloclavidae requires slight modifications to accommodate the new taxon within this family (see above).

The presence of a distinct fosse and parapet is also present in the family Andresiidae. However, members of this family are characterised by a well defined, circumscribed, endodermal sphincter, two siphonoglyphs and 24 pairs of perfect mesenteries.

The systematic position of the family Andresiidae is another instance of the lack of phylogeny patterns in 
Table 1 Size ranges of the cnidae of Stephanthus antarcticus gen. nov., sp. nov.

\begin{tabular}{|c|c|c|c|c|c|}
\hline & Category & Figure & $\begin{array}{l}\text { Range of length and width } \\
\text { of capsules }(\mu \mathrm{m})\end{array}$ & Sample $^{a}$ & Frequency ${ }^{b}$ \\
\hline \multicolumn{6}{|l|}{ Physa } \\
\hline & Basitrichs 1 & & $(16.4-27.1) \times(2.5-4.1)$ & 5/5: 80 & $+/++$ \\
\hline Scapus & Basitrichs 1 & $6 \mathrm{~B}$ & $(18.0-23.8) \times(2.5-4.1)$ & 5/5: 59 & $+/++$ \\
\hline \multicolumn{6}{|l|}{ Fosse } \\
\hline & Basitrichs 1 & & $(14.8-21.0) \times(2.5-4.0)$ & $5 / 5: 69$ & $+/++$ \\
\hline & $\mathrm{Mc}^{\mathrm{c}}$. b-mastigophores & $6 \mathrm{E}$ & $(15.6-20.5) \times(3.3-4.9)$ & 5/5: 41 & $-1+$ \\
\hline \multicolumn{6}{|c|}{ Tentacles (proximal) } \\
\hline & Spirocysts & $6 \mathrm{~A}$ & $(22.0-37.7) \times(2.5-3.3)$ & 5/5: 80 & $++/+++$ \\
\hline & Basitrichs 2 & $6 \mathrm{D}$ & $(52.5-102.5) \times(4.1-4.9)$ & 5/5: 80 & $++/+++$ \\
\hline & Basitrichs 1 & & $(16.4-28.0) \times(3.3-4.0)$ & 4/5: 36 & \\
\hline \multicolumn{6}{|c|}{ Tentacles (distal) } \\
\hline & Basitrichs 2 & $6 \mathrm{C}$ & $(72.0-107.3) \times(4.1-5.0)$ & 5/5: 80 & +++ \\
\hline & Basitrichs 1 & & $(19.7-28.7) \times(2.5-4.1)$ & 4/5: 12 & - \\
\hline \multicolumn{6}{|c|}{ Stomodaeum } \\
\hline & Basitrichs 2 & & $(53.3-72.0) \times(4.9-5.7)$ & 5/5: 71 & +++ \\
\hline & Basitrichs 1 & & $(19.7-27.1) \times(2.5-4.1)$ & $5 / 5: 70$ & $+/++$ \\
\hline \multicolumn{6}{|c|}{ Filaments } \\
\hline & Basitrichs 1 & & $(18.0-27.1) \times(2.5-4.1)$ & $5 / 5: 80$ & $++/+++$ \\
\hline
\end{tabular}

Carlgren's system and some of its categories (which Carlgren himself recognised) and the necessary wholesale revision of the higher categories in the actiniarian taxonomy. According to Stephenson (1922, p 264), the single species in the genus (and in the family) Andresia parthenopea (Andres 1881) does not resemble a typical athenarian, except in the absence of basilar musculature and in a burrowing mode of life. Stephenson (1922) placed the genus Andresia in the family Andresiidae, including it within the Endomyaria. Carlgren (1949) grouped the Andresiidae within the athenarian tribe. Schmidt (1972) also placed the family within the Endomyaria.

Comparison of the new genus with the other haloclavid genera

The new genus shares the absence of acrospheres in the tentacles with Peachia (Gosse 1855), Mesacmaea (Andres 1883), Harenactis (Torrey 1902) and Metapeachia (Carlgren 1943) (see Carlgren 1949; Manuel 1988 for additional characters of these genera). Only the haloclavid genera Anemonactis (Andres 1881) and Haloclava (Verrill 1899) show distinct acrospheres at the apex of the tentacles. The imperfect mesenteries and no clear difference between the length of the outer and the inner tentacles distinguish Stephanthus gen. nov. from Anemonactis and Haloclava, in which all the mesenteries are perfect and the inner tentacles are shorter than the outer ones.
Stephanthus gen. nov. has imperfect mesenteries, whereas in Metapeachia, Mesacmaea and Harenactis, all mesenteries are perfect.

Metapeachia is easily distinguishable from the other haloclavid genera (including Stephanthus gen. nov.) by the presence of a siphonoglyph completely separated from the other parts of the actinopharynx. The presence of a distal conchula is another distinctive generic character of Metapeachia (shared only with Peachia). Furthermore Metapeachia has only eight pairs of mesenteries (all perfect and fertile) and 16 tentacles, while Stephanthus gen. nov. has 12 pairs of mesenteries (only six of them perfect) and 24 tentacles arranged in three regular cycles.

Mesacmaea is the only genus of the Haloclavidae (including Stephanthus gen. nov.) in which the column is divisible into different regions; moreover, it is clearly remarkable within the family due to the presence, although weak, of a diffuse sphincter. Mesacmaea also has a very regular arrangement of the tentacles but is quite atypical in having seven tentacles in the inner cycle. The retractor musculature is strong and restricted in Mesacmaea but is diffuse in Stephanthus gen. nov.

In Harenactis the retractor musculature of the oldest mesenteries is reniform, but it is diffuse in Stephanthus gen. nov. Harenactis also has vertical rows of cinclides in the column, Stephanthus gen. nov. has no cinclides.

Finally, Peachia shares with Stephanthus gen. nov. a second cycle of imperfect mesenteries, but Peachia is easily distinguishable from Stephanthus gen. nov. by having a distinct conchula. Also Peachia usually has on- 
ly 12 tentacles, its aboral end is perforated by numerous apertures, and its second cycle of mesenteries is formed by only four pairs of imperfect and sterile mesenteries. In contrast, Stephanthus gen. nov. has no conchula, 24 tentacles, an imperforate aboral end, and a distinct fosse and parapet, and its second cycle of mesenteries is formed by six regularly arranged pairs of imperfect and fertile mesenteries.

Riemann-Zürneck (2000) recently removed the genus Oractis to a new family, Oractiidae. Because of that, and the addition of Stephanthus gen. nov., the second part of the key to haloclavid genera given by Carlgren (1949, pp 29-30) is modified as follows:

2. Tentacles without acrospheres

1) All mesenteries perfect

a) Siphonoglyph separated from the actinopharynx, with a conchula; 8 pairs of mesenteries, all perfect

aa) Siphonoglyph without conchula, not separated from the actinopharynx

b) Column divisible into regions. Arrangement Mesacmaea of tentacles regular but atypical with 7 in the inner cycle. A weak, diffuse sphincter bb) Column not divisible into regions. No sphincter. Tentacles hexamerously arranged

2) Mesenteries not all perfect

c) Siphonoglyph with a conchula, rarely Peachia completely separated from the actinopharynx. Second cycle formed by only 4 pairs of imperfect and sterile mesenteries ( 2 ventral and 2 ventrolateral pairs)

cc) Conchula absent. Second cycle formed by 6 pairs of imperfect and fertile mesenteries. Well developed parapet and fosse present

One noticeable character of Stephanthus antarcticus sp. nov. is the absence in its cnidom of microbasic p-mastigophores. This absence is atypical; indeed, the microbasic p-mastigophore is one of the commoner nematocysts in the Actiniaria, usually present in the filaments and in the actinopharynx (Carlgren 1940; Fautin 1988; Östman 2000). Carlgren (1940, p 49) reported only four species within this order belonging to four genera lacking this type of nematocyst, namely: Eloactis (Andres 1883) (based on an unspecified species of Eloactis; currently Eloactis species are distributed between the genera Haloclava and Anemonactis, both Haloclavidae; see Carlgren 1949), Haliactis (fam. Haliactiidae) (Carlgren 1921), Boloceroides (fam. Boloceroididae) (Carlgren 1899) and Actinostephanus (fam. Actinodendronidae) (Kwietniewski 1897). Another notable feature is the long basitrichs (basitrichs 2, see Fig. 6C, D and Table 1) in the tentacles. The range of the basitrichs 2 in the proximal part of the tentacles is wider than that in the distal part of the tentacles, the longest basitrichs being more abundant in the distal part. Moreover, the length range of the basitrichs 2 is even more restricted in the stomodaeum than in the tentacles.
Acknowledgements Special thanks are addressed to Dr. JosepMaria Gili (Instituto de Ciencias del Mar, Barcelona) and Prof. Wolf Arntz (Alfred-Wegener-Institut, Bremerhaven), who made possible our participation in the Antarctic cruises where the present material was collected.

Dr. Karin Riemann of the Alfred-Wegener-Institut Bremerhaven, Germany, is thanked for her friendly and helpful comments and advice. Comments and suggestions from Daphne Fautin greatly improved this manuscript. Thanks to Dr. Angel M. Pastor for his helpful assistance in taking some of the microphotographs of this work. The authors also acknowledge the helpful assistance of the Department of Cellular Biology of the University of Seville for the use of histological equipment. Thanks also to M. Conradi (University of Seville) who collected the additional material of this manuscript for us. We extend our acknowledgements to the officers and crew of the R/V Polarstern, and many colleagues on board during the EASIZ-II and ANDEEP-I cruises for their valuable assistance. Tony Krupa is thanked for reviewing the English version. Support was provided by a MCT-CSIC grant (I3P-BPD2001-1) to E. Rodríguez, and Spanish CICYT projects: ANT97-1533-E, ANT98-1739-E, ANT99-1608-E, and REN20014269-E/ANT.

\section{References}

Andres A (1881) Prodromus neapolitanae actinarium faunae addito generalis actiniarum bibliographiae catalogo. Mitt Zool Stat Neaple II, Leipzig

Andres A (1883) Le Attinie. Atti R Accad Lincei Mem 14(3):211673

Appellöf A (1896) Die Actiniengattungen Fenja, Aegir, und Halcampoides, DAN. Afh Aarsberetning Udgivnet Bergens Mus 11:3-16

Arntz WE, Gallardo VA (1994) Antarctic benthos: present position and future prospects. In: Hempel $G$ (ed) Antarctic science: global concerns. Springer, Berlin Heidelberg New York, pp 243-277

Arntz WE, Brey T, Gallardo AV (1994) Antarctic zoobenthos. Oceanogr Mar Biol Annu Rev 32:241-304

Bayer FM (1981) Status of knowledge of octocorals of world sea. In: Seminarios de biologia marina, Sâo Paulo. Academia Brasileira Ciências, Rio de Janeiro, pp 3-102

Carlgren O (1899) Über abschnürbare Tentakel bei den Actiniarien. Zool Anz 578(22):39-44

Carlgren O (1921) Actiniaria. I. Dan Ingolf-Exp 5(9):1-241

Carlgren O (1940) A contribution to the knowledge of the structure and distribution of the cnidae in Anthozoa. Lunds Univ Arsskr 36:1-62

Carlgren O (1943) East-Asiatic Corallimorpharia and Actiniaria. Kongl Svenska Vetenskapsakad Handl (Ser 3) 20(6):1-43

Carlgren O (1949) A survey of the Ptychodactiaria, Corallimorpharia and Actiniaria. Kongl Svenska Vetenskapsakad Handl (Ser 4) 1(1):1-121

Dunn D (1983) Some Antarctic and sub-Antarctic sea anemones (Coelenterata: Ptychodactiaria and Actiniaria). (Biology of the Antarctic Seas XIV, Antarctic research series 39) AGU, Washington, D.C., pp 1-67

Gabe M (1968) Technique histologique. Massou et Cie, Paris

Gosse PH (1855) Description of Peachia hastata, a new genus and species of the class Zoophyta; with observations on the family Actiniadae. Trans Linn Soc Lond 21:267-276

Fautin D (1984) More Antarctic and sub-Antarctic sea anemones (Coelenterata: Corallimorpharia and Actiniaria). (Biology of the Antarctic Seas XIV, Antarctic research series 41) AGU, Washington, D.C., pp 1-42

Fautin D (1988) Importance of nematocysts to Actinian taxonomy In: Hessinger DA, Lenhoff HM (eds) The biology of nematocysts. Academic Press, San Diego, pp 487-500

Hand C (1966) On the evolution of the Actiniaria. In Rees WJ (ed) The Cnidaria and their evolution. Academic Press, London, pp 135-46 
Johansen DA (1940) Plant microtechniques. McGraw Hill, New York

Kwietniewski CR (1897) Ein Beitrag zur Anatomie und Systematik der Actiniarien. Universität Jena, Germany

López-González PJ, Gili JP (2001) Rosgorgia inexpectata, new genus and species of Subergorgiidae (Cnidaria, Octocorallia) from off the Antarctic Peninsula. Polar Biol 24:122-126

Manuel RL (1988) British Anthozoa. In: Kermack DM, Barnes RSK (eds) Synopses of the British fauna (new series no18, revised). Brill/Backhuys, Leiden

Östman C (2000) A guideline to nematocyst nomenclature and classification, and some note on the systematic value of nematocysts. Sci Mar 64 [Suppl 1]:31-46

Riemann-Zürneck K (1979) Two disc-shaped deep sea Anthozoa from the Gulf of Biscay, with a survey of adaptation types in the Actiniaria. Zoomorphologie 93:227-243

Riemann-Zürneck K (1991) The abyssal sea anemone Kadosactis sulcata Carlgren, 1934 (Cnidaria: Actiniaria: Kadosactidae nov. fam.). Senckenbergiana Marit 21(5/6):191-204

Riemann-Zürneck K (2000) Oractis bursifera sp. nov., an Arctic deep-sea anemone with peculiar invaginations of its oral disc (Cnidaria: Actiniaria). Polar Biol 23:604-608

Rodríguez E, López-González PJ (2002) A new species of Halcampella (Actiniaria, Halcampoididae) from the eastern Weddell Sea and Antarctic Peninsula. Sci Mar 66:43-52

Schmidt H (1972) Prodromus zu einer Monographie der mediterranen Aktinien. Zoologica 422 (121):120
Schmidt H (1974) On evolution in the Anthozoa. In: International Coral Reef Symposium 1, Great Barrier Reef Committee, Brisbane, pp 533-60

Shick JM (1991) A functional biology of sea anemones. In: Calow P (ed) Functional biology series. Chapman and Hall, London

Stephenson TA (1920) On the classification of Actiniaria. I. QJ Microsc Sci 64 (256): 425-574

Stephenson TA (1922) On the classification of Actiniaria. III. QJ Microsc Sci 66: 247-319

Torrey HB (1902) Papers from the Harriman Alaska Expedition. XXX. Anemones, with discussion of variation in Metridium. Proc Wash Acad Sci 4:373-410

Verrill AE (1899) Art. VI. Descriptions of imperfectly known and new Actinians, with critical notes on other species. II. Am J Sci 7(4):41-50

Watling L, Thurston MH (1989) Antarctica as an evolutionary incubator: evidence from the cladistic biogeography of the amphipod family Iphimediidae. In: Crame JA (ed) Origins and evolution of the Antarctic biota. (Special publication 47) Geological Society, London, pp 297-313

Williams GC (1999) Index Pennatulacea: annotated bibliography and indexes of the sea pens (Coelenterata: Octocorallia) of the world 1469-1999. Proc Calif Acad Sci 51(2):19-103

Winston JE (1992) Systematics and marine conservation. In: Eldredge N (ed) Ecology and the biodiversity crisis. Columbia University Press, New York, pp 144-168 